doi: $10.19090 /$ i.2019.30.157-170

\author{
NATAŠA HENIG MIŠČIČ \\ Institute of Contemporary History, Ljubljana \\ natasa.henig@inz.si
}

\title{
ECONOMIC AND ALTRUISTIC MOTIVES IN PHILANTHROPIC WORK OF THE CARNIOLAN SAVING BANK 1844-1908
}

\begin{abstract}
The article discusses the different reasons for very enthusiastic philanthropic work of the Carniolan Savings Bank. During the second half of the 19th century the social issue appeared in a changed form as an urgent question of improving the financial position of an increased number of poorer strata of the society. The management of the Carniolan Savings Bank was aware that the financial resources they collected could help with overcoming hardship and contribute to the general good. The board of the Carniolan Savings Bank donated a part of its net income for charity purposes every year. The paper deals with the period from 1844, the year of the proclamation of the Savings bank regulation, which allowed the use of surpluses for charitable and non-profit purposes. The period under scrutiny ends with the year 1908, when the Carniolan Savings Bank changed its policy of philanthropic activities because of the consequences that it faced after the "run" and boycott of the Slovenian part of the population in the Carniola province.
\end{abstract}

Keywords: Carniolan Savings Bank, philanthropy, charity work, donations, Regulation, boycott.

\section{Introduction}

$\mathrm{M}$ odern philanthropy, shaped in the period of the industrial revolution and institutionalizing itself in response to the "social question", is partly distanced from traditional charity, which was more oriented in the discretion of religious institutions and arbitrariness generosity entrusted. Instead, philanthropy, as evolved and organized in the $19^{\text {th }}$ century, tends to replace the old local form of the manipulation or suppression of problems and social conflicts with a demand for rationalization and centralized coordination. The immediate political dimension of philanthropic practices makes it a plaything for social conflicts between groups of different positions. Because philanthropy generates a social bond between the giver and the recipient, it has often been able to restore social peace. ${ }^{1}$

The development of humanitarian activity has also stimulated individual and

1 David, Guilhot and Mazburi 2006: 10-14. 
institutional charity towards more determined action. Private charity and public concern were complementary to each other and each pursued the same goal, social happiness. There is no doubt that philanthropic initiatives were beneficial. To help the poor, they tried to mitigate the effects of the deterioration of the material situation of the poorer strata of society and set them on the verge of social indifference. ${ }^{2}$

Institutions and social ties in local communities were the most reliable support for charitable programmes. From the outset, the economic thought has established a close connection between the sense of belonging to the local community and the sense of responsibility that the local community felt about its members. When the role of the central authority grew in the field of social assistance, the increasing scope of its interventions influenced the content of the term "local responsibility" and gradually expanded it to cover the whole nation or even the state. ${ }^{3}$

\section{Savings banks as philanthropic institutions}

In the first half of the $19^{\text {th }}$ century, a period of dynamic economic development, the idea of the savings bank was introduced. These institutions were involved in financial and general economic processes. The purpose of the establishment of savings banks was to bring people closer to the potential of the storage of earned money. The main target group were low-income households because banking services were only available to affluent people. By increasing the savings rate, savings banks had the opportunity to increase the accumulation of the capital and thereby contribute to the economic growth in general. At the same time, they had the status of a charitable foundation, which was very important for their founders or owners, as well as for the state authorities, which supervised their operations. Less wealthy sections of the populations mostly benefited from savings banks. ${ }^{4}$

The paper deals with a very important area of the activity of savings banks connected to philanthropic or social commitment. There were two kinds of philanthropy in which savings banks were involved. In the first place, the fight against financial exclusion stands out among the original objectives that savings banks were given, by means of promoting savings and granting loans to less wealthy social strata. The financial activities of savings banks included a charitable component. Nevertheless, their financial activity brought benefits to the society as a whole. Because they did not have to distribute private dividends, they could use undistributed profits to finance different social programmes, which constituted the other part of their philanthropic activity. The social dividend consisted of giving back to the society the net profits that were not put in their reserve funds. During the $19^{\text {th }}$ century together with the state savings banks contributed to charitable works aimed at improving the conditions for the poor and combating their financial exclusion. They were founded by private entrepreneurs, imbued with the altruistic ideas of the Enlightenment, but regulated by the state so that they would contribute to encouraging saving among the poorer

\footnotetext{
Geremek 1996: 270.

Ibid. 269-271.

Dirninger 2007: 10-11.
} 
strata of the society. This enabled the poor to join the financial market. ${ }^{5}$

The founders of savings banks were largely philanthropists who wished to improve the living conditions for the vast majority of the people. They had three basic principles that can be defined. The first principle is the aim of savings banks to encourage saving. The second principle is their close local support, and the third principle is their particular nonprivate profit organizational form. Promoters of savings banks at the beginning of the $19^{\text {th }}$ century were leading personalities in the local communities like clergymen, industry owners and military officers who wished to contribute their share to communities and individuals. The founders did not primarily serve their own interests and a proof of that was a great amount of unpaid work within the banking establishment. Savings banks were created for the benefit of the poor part of the population. ${ }^{6}$ During the period when a savings bank system was first established in the provincial capitals of the Habsburg state, these institutions were based on the principle of the "social issue" in the form of early industrial pauperism.

\section{Carniolan savings bank as an institution for poverty alleviation}

The Carniolan Savings Bank was the first and central financial institution in the Slovenian territory. It was founded in 1820 by a group of entrepreneurs in Ljubljana, the capital city of Carniola, a province in the Austrian part of the Habsburg Monarchy. The Carniolan Savings Bank eventually became one of the most important financial institutions, managing people's savings and encouraging them to save money. At the same time, it collected deposits and managed credit activity in the country. Savings banks had also a philanthropic character and, over time, they developed into an important and crucial bearer of economic, social, cultural and political development.

The Carniolan Savings Bank was the second established savings bank in the Habsburg Monarchy, only one year after "Erste Österreichische Spar-Casse" in Vienna, which was opened for business in October 1819. The founder of the Erste Österreichische Sparkasse was Johan Baptist Weber, a parish priest in the Vienna suburb of Leopoldstadt. Weber collected a guarantee fund for a new institution among the citizens of his parish. In a popular essay he described the general benefits of savings banks and wanted to encourage the creation of savings banks in other parts of the country. ${ }^{8}$

During the first two years, the Carniolan Savings Bank operated as an association with the Provisional Statute. The Statute with administrative rules was approved on 1 March 1822 and it was valid until the announcement and acceptance of the state Savings bank regulation on 2 November 1844. In the first Provisional Statute it was written: "the Savings Bank in Ljubljana has the intention to offer everybody, but especially less wealthy people, an opportunity to invest their savings and eventually multiply, thereby stimulating and

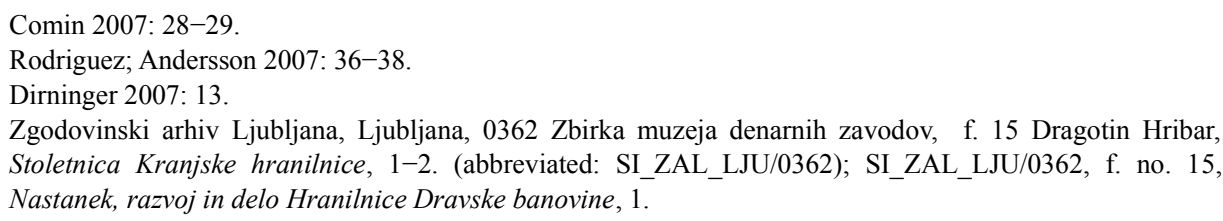


reviving diligence and thrift." 9

The Carniolan Savings Bank was organized as a philanthropic association. It was established without a founding fund or other capital, similar to the one the local authorities usually demanded from an institution oriented to profit making. The Savings Bank did not give its members any profits or other benefits such as dividends. The leading members of the savings bank's association performed all the work without any compensation and they were committed to guaranteeing the proper payment of every demand for deposit withdrawal and promised interests. "This humanitarian activity of the Carniolan Savings Bank was, in essence, what strengthened the faith of the population in its proper business much more than the possible strict securing of its deposits." 10 Therefore, during the first period of its operation the association of the savings bank carefully selected the leading members and the advantage was given to influential people, primarily those who enjoyed the confidence of the wider layers of the population in the Carniola province. Of course, the increasingly favourable situation of the savings bank's assets and the development of a reserve fund strengthened the faith in the stability of the institution. ${ }^{11}$

During its existence, the Carniolan Savings Bank established several institutions with various charitable purposes. The first of all was a pawnshop, which began operating in 1835. This institution functioned until 1910 when it was finally liquidated, which was a consequence of a boycott from 1908. After the first expansion of business in 1828 unused money remained in the cash register of the savings bank. Therefore, the management adopted a decision to establish a special pawnshop following the example of similar institutions in Graz and Klagenfurt. The purpose of this institution was to act for the public good and especially for the poorest inhabitants of the Carniola province. The pawnshop opened for business on 4 November 1835 , on the $15^{\text {th }}$ anniversary of the Carniolan Savings Bank. ${ }^{12}$ The pawnshops, financed by the savings banks, enabled the most deprived to escape from the clutches of the moneylender, to whom they paid high-interest rates. ${ }^{13}$ The pawnshop showed a considerable annual turnover in the first years of its operation. For this reason, it quickly became popular among the poorer social strata because it protected them from usurious persons. Nevertheless, the expectations of the savings banks' management that the loans they gave to the pawnshop would make a profit had not been fulfilled. The expenditures of pawnshop exceeded their income and the savings bank had to cover this loss out of its own income. ${ }^{14}$

\section{Philanthropic work of the Carniolan Savings Bank 1844-1884}

An essential element of the work of the savings bank, which must be regarded as constitutive from the beginning, was a special way of using surpluses of net profits. The

\footnotetext{
9 Arhiv Republike Slovenije, Ljubljana, 437 Hranilnica Dravske banovine, f 38, Provisorische Statuten der Sparcasse in Laibach, 20. 10. 1820, 2. (abbreviated: SI AS 437)

10 SI AS 437, f. 38, Ustanovitev Kranjske hranilnice, 8.

11 Ibid.

SI AS 437, f. 38, Ustanovitev Kranjske hranilnice: 11-12.

Comin 2007: 29.

Kranjska hranilnica v Ljubljani 1910.
} 
savings had to take into account the fact that the profit surplus could only be used for purposes that served the common good and for the interest of the majority of their depositors. While Karl Friedrich von Kübeck in his 1842 eulogy wanted to see the main use of these profit surpluses for the payment of savings premiums to the owners of the smallest depositors, the rule speaks generally of use for charitable or non-profit local purposes. This fact of the non-profit use of surpluses did not bring about a fundamental change, only a considerable appreciation. It was understood as a dominant, if not exclusively determining characteristic of the general term "charity of the savings banks". ${ }^{15}$

In September 1844 the state authorities published the "Sparregulativ" (Savings bank regulation), which represented the general rules of the establishment and operation of savings banks in local communities. The twelfth article of the regulation allowed savings banks to use part of their net profit for charity purposes. It was introduced by the state Commissioner, who supervised the business and reported to the state authorities. Savings banks were able to accept all types of deposits, but they had to set a minimum and a maximum amount. Here we can see how authorities tried to limited savings banks to small savings because it was not supposed to be a place of fructification of greater capital sums. They were aware that they could help with decreasing and overcoming distress and contribute to general well-being. ${ }^{16}$ The state explicitly defined the socio-political function and hence the public functioning of savings banks through the Savings banks regulation. The socio-political activity was in this way part of the explicitly standardized structure of the savings banks' operations. An important starting point was the mentioned maximum allowed deposit amount, which changed over time until it was abolished in the early 1870s. In this way, the savings bank wanted to direct its attention to the lower social classes, making it less attractive to the wealthy population. The greater capital investments were accepted with the commission. The payment of interest for small deposits was guaranteed. ${ }^{17}$

The twelfth article of the Regulation allowed savings banks to use part of their net profit for charity purposes. "When the reserve fund reaches a higher amount than is necessary for the operations of the institution, and unless otherwise provided in the Statute of Association, a certain amount may be used for charitable purposes with the prior approval of the supervisory authority." 18 In the continuation of the same article, however, it was stipulated that each savings bank had to have a special reserve fund, which should cover all possible losses in business. ${ }^{19}$ The authority determined this reserve fund based on the performance and size of the business of the savings bank. ${ }^{20}$ Members of the savings bank's association were aware that their collected funds might also contribute to the elimination of distress and contribute to the overall good. The book published for the fiftieth business anniversary of the Carniolan Savings Bank informs us that they found their satisfaction through the efforts to contribute to the society. ${ }^{21}$

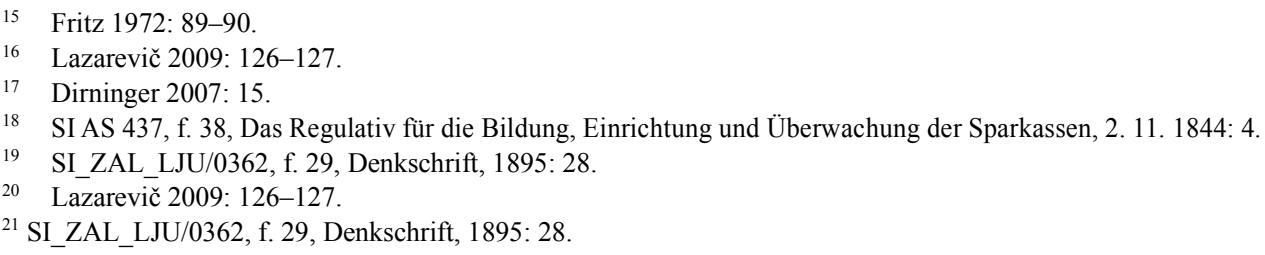


The state explicitly defined the socio-political function and hence the public functioning of a savings bank with the help of the Savings bank regulation. In this way, the socio-political activity became part of a standardized system of the structure of the savings bank's operations. If a savings bank wanted to be attractive to less wealthy social classes, the minimum deposit amount that the savings bank was receiving had to be as low as possible, so the poorest layers of the society had the possibility to open deposit accounts. ${ }^{22}$ Paid interests were benefits just for small deposits and lower deposits gained higher interest rates. Although the Regulation from 1844 stipulated that surpluses were used for charitable and non-profit local purposes, savings bank, nonetheless, preferred the security of deposits and the pupillary safety of investments. ${ }^{23}$

Every year the board of the Carniolan Savings Bank donated part of its net income to charity purposes. In the aforementioned book published on the occasion of the celebration of the $50^{\text {th }}$ anniversary of the existence of the Carniolan Savings Bank, we can find a list of all beneficiaries of the aid from the Savings Bank from the time of the proclamation of the Savings bank regulation in 1844 until 1870 . The total amount of the money paid to charity was 112,383 florins. It is evident from the list that the recipients were mostly poor and sick people who were unable to work. In addition, a lot of money was given to various schools and poor students. ${ }^{24}$ The Carniolan Savings Bank was offering scholarships for poorer students as well. At the General Assembly on 19 February 1863 it was decided that four scholarships of 150 florins for the next school year would be awarded to students who, after a successful secondary school or high school, would devote themselves to technical studies abroad. The students would receive these scholarships until they finished their technical studies. ${ }^{25}$

\section{Philanthropic work of the Carniolan Savings Bank 1884-1908}

The beginning of the 1880 s was marked by a change in the political position of the Germans in the Carniola province and in Ljubljana. In the Carniola province Germans accounted for about five percent of the population. Until 1882 they were heads of the city council and the capital of Ljubljana and until 1883 they had a majority in the provincial assembly. In the period 1883-1893 it was in the interests of Carniolan Germans to have advantage over the control of the financial institution of the Carniolan Savings Bank. This control gave them a great deal of influence on the financial-economic and, consequently, on the cultural and political situation in the Carniola province although their political power was significantly reduced. This impact was not proportionate to their numerousness but rather to their financial and intellectual capacity. ${ }^{26}$

National and political differentiation was followed by national battles. Differentiation began in the 1860 's and early 1870 's. ${ }^{27}$ During this period it was

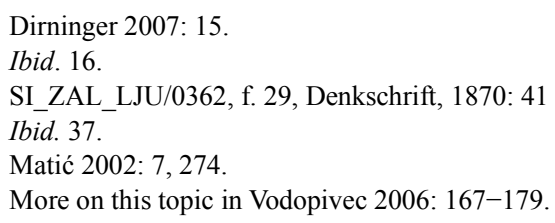


characteristic that people usually decided in the elections by voting for the Slovenian national party, its programme and performance, or against it. On the opposite side were Slovenians, who for any of the possible reasons did not like the Slovenian party, then Slovenians and Germans, who were satisfied with the traditional leading role of the German language and culture, ${ }^{28}$ Slovenians and Germans, who believed that national requirements were not so important, but constitutional acquisitions, fight for their preservations and promotion of liberal ideas were. ${ }^{29}$

National differentiation had a different path in each province. Carniola was practically the land of Slovenians and in Ljubljana the relative proportion of Germans was always small. The Carniola province had a tradition of the country with the Slovene population and the Slovene language. The situation in Lower Styria, for example, was completely different. Germans lost the countryside, but they had a city curia in Celje, Maribor and Ptuj in their hands until the end of the monarchy, while Slovenes were part of a large country with a German majority and a German centre. In Lower Styria, after 1878, all electoral districts of the peasant curia and after 1907 all rural state electoral districts were in the hands of Slovenes. ${ }^{30}$

During 1884 there was a debate in the provincial assembly about the control over the reserve fund of the Carniolan Savings Bank. Representative Luka Svetec proposed a bill that would introduce the control of the provincial assembly over the reserve fund. "The purpose of the new bill [...] is to put the reserve fund of the Carniolan Savings Bank in Ljubljana, insofar as it is intended for charitable, commonly-beneficial local and provincial purposes, under the supervision of the Provincial Assembly." ${ }^{31}$ In the continuation of his speech he tried to convince other members of the assembly that "if this fund turns well, if this fund is in the hands of people who are friendly, how much good can be done for the country! and, of course, you will be willing to affirm, if I say, it is worthwhile to stretch out our best power to preserve this fund for the country." 32 The outrage over such attempts to take control of the institution, which had always been generous to the country, was irreplaceable on the German side. Josef Schwegel decisively challenged the law proposal in a debate in the Provincial assembly on 16 October $1884 .{ }^{33}$ Provincial president Baron Andrej Winkler was also against the proposal: "I regret that I cannot approve this proposal, because according to $\S 27$ of the relevant Regulation and also $\S 22$ of the statute of the Carniolan Savings Bank Association of 26 November 1852, the right to control the savings bank is reserved only for the government, so from my point of view, as a representative of government, I could not agree to share this right with anyone else. [...] I cannot see the practical need for that besides the government if someone else supervises the savings bank's fund, because the government and its representatives have the duty, not only the rights, to look after the proper management of the savings bank's assets." 34 Nevertheless, the

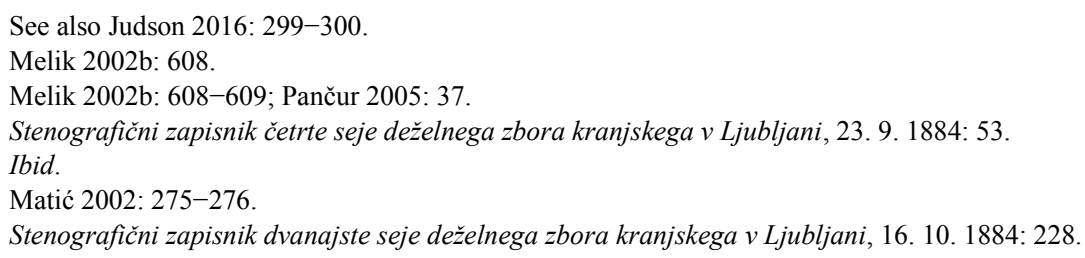


Slovenian majority adopted the law, while the German minority left the hall. However, the law did not receive the emperor's confirmation. ${ }^{35}$

The process of industrialization, other processes of modernization and urbanization, as well as continued immigration and constant population growth contributed to the escalation of housing problems. The most significant was the deficiency of small and cheap apartments. ${ }^{36}$ Therefore, in 1883 the Board of the Carniolan Savings Bank decided to allocate a special amount of 100,000 florins to the fund for the construction of apartments that were financially more accessible to workers. They saw building new apartments as a very nice opportunity for a practical and important step in solving some of the social questions. In 1886, at the initiative of the Carniolan Savings Bank, a foundation for the construction of working-class housing was established. Next year, the foundation started building workers' houses on the land along the Vienna State Road in Bežigrad, which was later called the "Savings bank street." ${ }^{37}$ After the death of Josef Luckmann, long-time President of the Carniolan Savings Bank in 1906, the savings bank donated 40,000 crowns to the Association for the construction of workers housing to build a house for workers which was to be named "Josef Luckmann house." 38 In addition, the savings bank decided to set up a fund for poor industrial workers and their relatives on Luckmann's behalf. ${ }^{39}$

At the general assembly in 1895, the Carniolan Savings Bank Society adopted a resolution on the imposition of the Institute for Incompatible Patients. They set up a special fund in which they invested a million crowns to maintain the institute and to cover the costs of building the institute's building. Finally, on the basis of the Charter from 5 July 1897, which was approved by the Provincial Government of Carniola on 17 November 1897, an institution called The Emperor Franz Joseph's Patient Shelter was established. It was intended for "free care of incurable poor patients from the Carniola province." The institute was formally opened on the $19^{\text {th }}$ anniversary of the Carniola Savings Bank in $1910 .{ }^{40}$

At the end of the $19^{\text {th }}$ century, the Austro-Hungarian Monarchy experienced national polarization. ${ }^{41}$ It was not enough to be just Slovenian or German, it was necessary to show nationality in the public. National struggles intensified in the Slovenian territory at the turn from the $19^{\text {th }}$ to the $20^{\text {th }}$ century. ${ }^{42}$ A number of excesses which happened tell us that the national struggle over time could gain the dimension of the struggle for life and death. During the last decades before the outbreak of the First World War, contradictions between Slovenes and Germans reached great proportions. One of the most prominent conflicts was the September 1908 event that began with the German protests in Ptuj and reached the peak with anti-German demonstrations in Ljubljana. ${ }^{43}$

Very significant for the mentioned period was the strong movement in the securities

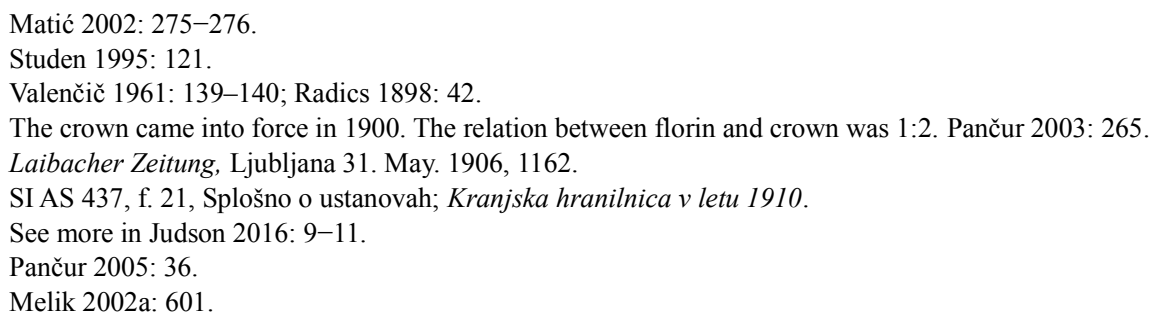


markets. The liberalization of the market and the large supply of free capital forced the National Bank to lower the interest rate. On the other hand, the time before the outbreak of the First World War was marked by steady growth in deposits, although much slower than in the previous period. There were several reasons for this. Initially, it slowed down and reduced the founding activity of savings banks, which in general in the Austrian part of the monarchy reached the greatest intensity between 1860 and $1880 .{ }^{44}$ Moreover, the beginning of the $20^{\text {th }}$ century brought rapid development of other financial institutions such as credit cooperatives, joint stock companies and banks. ${ }^{45}$

Despite economic integration, which was accelerated in the second half of the $19^{\text {th }}$ century, the political and social differences between individual nations in the AustroHungarian monarchy were growing. ${ }^{46}$ Austro-German economic strength was not able to dominate the huge empire, a dialogue with the different nationalities was necessary, but most of all, a huge gap between the urban, industrialized and the largely rural, traditional areas in the Austro-Hungarian Monarchy had to be bridged.

From the beginning of the 1880 s, Slovenians tried to take over the Carniolan Savings Bank. They wanted to gain control, particularly in order to prevent its support to German cultural and other societies and to prevent attempts at the establishment of the German system of folk education, which was one of the objectives of the management of the Carniolan Savings Bank. They tried to set up a savings bank under the control of the Provincial Assembly, in which Slovenians had a majority, but they failed. On the other hand, at the same time, there were tendencies for the defence of the national-economic positions and institutions of Germans in the Carniola province. They pleaded for the defence of the Carniolan Savings Bank, which was considered to be the financial pillar of Germans in Carniola. ${ }^{47}$ It was very important for institutions to have Slovene leadership and management in financial institutions because that was a criterion of national interest. Otherwise, the institution was placed on the opposite political and national side, as was the case with the Carniolan Savings Bank. ${ }^{48}$ The Carniolan Savings Bank was not only considered an economic but also a political symbol of German power in the Carniola province. ${ }^{49}$ In addition to the accusations that it was on the German side, the Slovene population has been criticized the savings bank because it had been ignoring Slovenian institutions. That was one of the reasons why in their eyes it continued to be considered as a German monetary institution.

Finally, Slovenian politicians decided to destroy the Carniolan Savings Bank. They encouraged massive withdrawals of savings and undermined the confidence in its credibility by spreading untruthful rumours of business irregularities and insolvency. Many people, especially from the countryside, withdrew their savings from the Carniolan Savings Bank day after day. The Slovene people were informed about "the run" by liberal newspaper Slovenski narod. In the newspaper, they openly called for a boycott of the Carniolan Savings

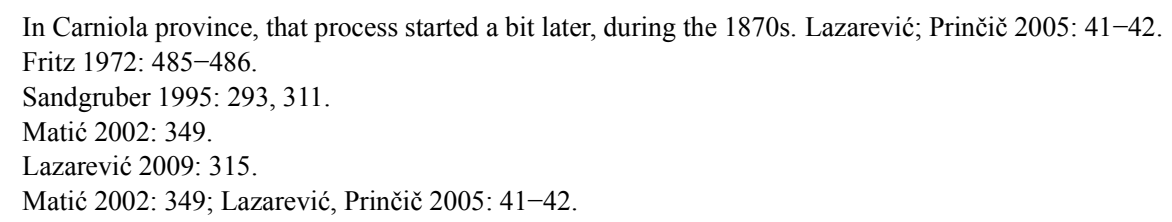


Bank and encouraged a fast response of Slovenian depositors to withdraw their savings. ${ }^{50}$

The consequences of the September events were felt everywhere and were very profound and irreversible. Although the broken windows in Ljubljana were quickly repaired and many offenders received monetary and prison sentences, distrust and hatred between Slovenes and Germans were still increasing. Most of the changes took place in Ljubljana. The example was its external appearance, which completely changed and had since then a Slovenian feature: "Only Slovenian white street signs on the green field have become a recognizable mark of the Slovenian white city of Ljubljana." German and bilingual inscriptions on shops disappeared and just Slovenian signs prevailed. In the opinion of Goropevšek, the annexation of Bosnia and Herzegovina a few weeks after the September events was crucial because September riots diminished and the big international political crisis that followed in the coming months emerged as prevalent. ${ }^{51}$

The money that the Savings Bank had to pay between October 1908 and June 1909 far exceeded all of its available cash. Deposits were in decline for several years. In addition, the sale of securities did not suffice the growing demands. Therefore, the Savings Bank stopped with approvals of new credits and started realizing mortgage and municipal loans, not just in the Carniola province, but also in other parts of the Monarchy. In order to secure money without compromising its reserve fund, they started selling real estates which they owned. ${ }^{52}$

Based on the statistics, we can conclude that the Savings bank successfully discharged obligations from debtors who lived outside the Carniola province. In 1908 the level of mortgage loans for the debtors from the Carniola province with a regular interest rate stayed at the same level as in the previous years. A major change occurred the following year when the approved loans amounted to only $25 \%$ of the discharged obligations. Although the level fell by only $9 \%$ at the end of 1909 , there were not so many fluctuations in this section in the following years, since the Savings Bank granted more newly approved loans. At the end of the year, the balance reached the pre-crisis level. On the other hand, the amount of discharged obligations for all those who lived in other parts of the Monarchy reached a peak in 1909. During 1909 a record 14 million crowns were paid to the Carniola Savings Bank. At the end of the year the amount reached only $31 \%$ of the one from the previous year. ${ }^{53}$

At the general assembly of the Carniolan Savings Bank on 30 December 1909 a decision was made to change the inscription on the building, which was in the Slovene language from that moment. Although the Savings Bank replaced the inscription on its building and started publishing its annual reports in the Slovene language, it was still considered a German financial pillar in Carniola. Annual reports contain lists of their social and charitable work. Every year the Carniolan Savings Bank dedicated a certain amount to various institutions from net profit. The highest support was provided to German institutions such as the Philharmonic Society in Ljubljana, Theaterverein, the German kindergartens in Ljubljana, Tržič, Zagorje and Kočevje and the Kranj section of the German Mountain Society.

\footnotetext{
Ibid.

Goropevšek 1998: 120 .

SI AS 437, f. 38 Zgdovina hranilnice od 1909 do 1918: 1.

Kranjska hranilnica $v$ Ljubljani $v$ letu 1909.
} 


\section{Conclusion}

During the $19^{\text {th }}$ century the Carniolan Savings Bank was very important as a means to foster thrift among poor people. Besides the benefits for individuals, the Savings Bank increased capital mobilization and served the local communities through the provision of charity donations. It was founded by a group of successful entrepreneurs under the influence of altruistic motives of the Enlightenment. They wanted to follow the example of the capital city with a similar institution that served as an example. The Carniolan Savings Bank began as a project of people who felt the need to give back to the society in some way. They certainly had different motives for their charity work, both economical and altruistic. The surpluses were primarily aimed at individuals and institutions which urgently needed financial support. Nevertheless, they paid great attention to their reputation. A number of articles from various newspapers speak about this. The Carniolan Savings Bank regularly sent a short overview of the activities from the previous year, which was published annually by the newspapers at the beginning of March. In short, articles presented their business success, which was followed by a very detailed list of all charity and the so-called "beneficial gifts".

The Carniolan Savings Bank provides a very good example that illustrates the influence of politics and nationalism on the economy. The first change occurred in the early 1880 s when a period of intense political and national differentiation started. The Carniolan Savings Bank was the central financial institution in the province and a very important factor in economic development. It was important who had control over its operations. In very tough circumstances, the peak of September events in 1908 brought a new change. The Savings Bank decided under pressure to give money donations only to those who remained loyal to it.

\section{REFERENCES:}

Archive sources:

Archive or Republic Slovenia, Ljubljana, Hranilnica Dravske banovine, (SI AS 437)

Historical Archive Ljubljana, Ljubljana, Zbirka muzeja denarnih zavodov. (SI_ZAL_LJU/0362)

Periodical:

Laibacher Zeitung, Ljubljana, 1906.

Published sources:

Kranjska hranilnica v letu 1909. Ljubljana: Kleinmayr \& Bamberg, 1910.

Kranjska hranilnica v letu 1910. Ljubljana: Kleinmayr \& Bamberg, 1911.

Obravnave deželnega zbora kranjskega v Ljubljani: Stenografični zapisnik četrte seje deželnega zbora kranjskega v Ljubljani, 23. 9. 1884 (online via: http://www.dlib.si/stream/URN:NBN:SI:DOCN984U5B0/b5c374b4-5cd2-47cd-87f3-af08b7a88335/PDF)

Obravnave deželnega zbora kranjskega v Ljubljani: Stenografični zapisnik dvanajste seje deželnega zbora kranjskega v Ljubljani, $16.10 .1884 \quad$ (online via: http://www.dlib.si/stream/URN:NBN:SI:DOC-PCOLDPKN/61daf90c-c1bd-494c-bcbb3 fcc664ede09/PDF) 
References:

Comin, F. Historical roots of the social commitment of savings banks in Spain - From charity to corporate social responsibility (1835-2002), 9th European Symposium on Savings Banks History, European Savings Banks: From Social Commitment to Corporate Social Responsibility, Madrid 4-5 May 2006. Perspectives, 55, 2007, 27-33.

David, T. Guilhot, N. and Mazburi, 'Einleitung: Philanthropie und Macht, 19. und 20. Jahrhundert.' Traverse. Zeitschrift für Geschichte - Revue d'histoire, 13, 2006, 7-17.

Dirninger, C. Historic dimension of corporate social responsibility (CSR) of savings banks - the Austrian example, 9th European Symposium on Savings Banks History, European Savings Banks: From Social Commitment to Corporate Social Responsibility, Madrid 4-5 May 2006. Perspectives, 55, 2007, 9-18.

Fritz, H. 150 Jahre Sparkassen in Österreich. Geschichte. Wien: Sparkassenverl., 1972.

Geremek, B. Usmiljenje in vislice. Zgodovina revščine in milosrčnosti, Ljubljana: Studia humanitatis, 1996.

Goropevšek, B. 'Odmev in pomen septembrskih dogodkov leta 1908. Spomin na 90-letnico dogodkov', u: Stane Granda, Barbara Šatej, Slovenija 1848-1918. Iskanje lastne posti. Ljubljana: Zveza zgodovinskih društev Slovenije, 1998, 115-123.

Judson, P. M. The Habsburg Empire. A New History, Cambridge, MA: Belknap, 2016.

Lazarević, Ž. and Prinčič, J. Bančniki v ogledalu časa. Življenjske poti slovenskih bančnikov v 19. in 20. stoletju, Ljubljana: ZBS Združenje bank Slovenije, 2005.

Lazarević, Ž. Plasti prostora in časa. Iz gospodarske zgodovine Slovenije prve polovice 20. stoletja, Ljubljana: Inštitut za novejšo zgodovino, 2009.

Maltby, J. and Rutterford, J. 'Investing in charities in the nineteenth century. The financialization of philanthropy', in: Accounting History, 21/2-3, 2016, 263-280.

Matić, D. Nemci v Ljubljani 1848-1918, Ljubljana: Oddelek za zgodovino Filozofske fakultete, 2002.

Melik, V. 'Problemi slovenske družbe 1897-1914', u: Slovenci 1848-1918. Razprave in članki. Maribor: Litera. 2002a, 600-607.

Melik, V. 'Politične razmere na Štajerskem v času Napotnika', u: Slovenci 1848-1918. Razprave in članki. Maribor: Litera. 2002b, 608-620.

Hahn-Oberthaler, V., Obermüller, G. and Weiglein, M. 170 Jahre Sparkasse Oberösterreich, Linz: Allgemeine Sparkasse Oberösterreich Bank AG, 2019.

Pančur, A. V pričakovanju stabilnega denarnega sistema, Celje: Zgodovinsko društvo, 2003.

Pančur, A. 'Nacionalni spori', u: Jasna Fischer, Slovenska novejša zgodovina. Od programa Zedinjena Slovenija do mednarodnega priznanja Republike Slovenije 1848-1992. Ljubljana: Mladinska knjiga; Inštitut za novejšo zgodovino, 2005, 36-38.

Radics, P. Die Wohltätigkeit in Krain unter den Herrschen aus dem Hause Habsburg. Eine culturgeschichte Studie, Wien: Österreichisch-Ungarischen Revue, 1898. (online via: http://www.dlib.si/stream/URN:NBN:SI:doc-V60XKGDU/65eafa25-2b89-4ae3-994c4100fd2037f9/PDF)

Rodriguez, E. and Andersson, M. Adaptation of the savings banks' social approach to their evolving environment - Swedish savings banks and society, 9th European Symposium on Savings Banks History, European Savings Banks: From Social Commitment to Corporate Social Responsibility, Madrid 4-5 May 2006. Perspectives, 55, 2007, 35-57.

Sandgruber, R. Ökonomie und Politik. Österreichische Wirtschaftsgeschichte vom Mittelalter bis zur Gegenwart. Wien: Ueberreuter, 1995.

Studen, A. Stanovati v Ljubljani. Socialnozgodovinski oris stanovanjske kulture Ljubljančanov pred prvo svetovno vojno, Ljubljana: ISH - Institutum studiorum humanitatis, 1995. 
Thol, C. Poverty relief and financial inclusion. Savings banks in nineteenth century Germany. Brussels: WSBI-ESBG The Voice of Savings and Retail Banking, 2016.

Valenčič, V. Gradbeni razvoj Ljubljane od dograditve južne železnice do potresa 1. 1895. Kronika. Časopis za slovensko krajevno zgodovino, 9/3, 1961, 135-144. (online via: http://www.dlib.si/stream/URN:NBN:SI:doc-671UDSFW/9f911a39-d744-42a3-b0779fb14982bc6b/PDF)

Vodopivec, P. O gospodarskih in socialnih nazorih na Slovenskem v 19. stoletju, Ljubljana: Inštitut za novejšo zgodovino, 2006.

Internet source:

Erste oesterreichische Spar-Casse in: http://www.erstestiftung.org/en/erste-foundation/history/ 


\title{
НАТАША ХЕНИГ МИШЧИЧ \\ Институ за савремену историју, Љубљана \\ ЕКОНОМСКИ И АЛТРУИСТИЧНИ МОТИВИ У ФИЛАНТРОПСКОМ РАДУ КРАҢСКЕ ШТЕДИОНИЦЕ 1844-1908
}

\begin{abstract}
Резиме
У раду се разматрају различити мотиви који су Крањску штедионицу подстицали да се залаже за веома ентузијастично деловање на филантропском пољу. Чланак покрива период од 1844. године када је била проглашена државна регулатива за штедионице, којом је било омогућено коришћење остварених новчаних вишкова у добротворне и непрофитне сврхе. Разматрани период се завршава 1908. годином и последицама са којима је штедионица морала да се суочи услед економског притиска и бојкота дела словеначког становништва Крањске. Крањска штедионица је са посебном пажњом градила свој друштвени положај и слику о себи. У раду се посебна пажња посвећује положају додатног или алтернативног елемента државне социјалне политике, који су штедионице могле да заузму. Наиме, током друге половине XIX века, социјално питање се појавило у измењеној форми, као неизбежно питање побољшања егзистенцијалног потенцијала све већег броја нижих и средњих слојева друштва. Руководство Крањске штедионице је било свесно, да прикупљеним финансијским средствима могу помоћи у савладавању новонасталих тешкоћа и истовремено допринети општем добру. Зато је управни одбор штедионице сваке године донирао део својих нето прихода у добротворне сврхе. Осим тога, поједини богатији становници Крањске су своју заоставштину поверили штедионици, која је имала обавезу, да након њихове смрти, из преосталих финансијских средстава установи фонд за различите добротворне сврхе. На тај начин је штедионица могла да пружи додатну финансијску подршку сиромашним и болесним становницима Крањске. Штедионица је такође нудила стипендије сиромашнијим ђацима и студентима, рођеним у Крањској. Од осамдесетих година XIX века је посебна средства наменила изградњи станова и кућа за раднике. Крајем XIX и почетком XX века у Аустро-Угарској монархији је дошло до националне поларизације, која је захватила и територије које су настањивали Словенци. Више није било довољно изјаснити за Словенца или Немца, већ је било неопходно показати националну припадност у јавности. Пошто је Крањска штедионица представљала централну монетарну институцију у Крањској и као таква била веома важан фактор економског развоја покрајине, појавило се питање надзора над њеним пословима и резервним фондом. Врхунац затегнутих односа, који су се интензивирали током прве деценије XX века, представљају Септембарски догађаји из 1908. године који су довели до коренитих промена у Љубљани и у Крањској. Последице економског притиска који је следио, осетила је и Крањска штедионица, чије водство је одлучило да новчане донације и помоћ пружи само онима који су јој остали лојални.
\end{abstract}

Кључне речи: Крањска штедионица, филантропија, добротворни рад, донације, Регулатива, бојкот. 